Original Article

\title{
Assessment of Cholinesterase inhibition activity of birds inhabiting pesticide exposed croplands and protected area in hot semi-arid region of Pakistan
}

\author{
Avaliação da atividade de inibição da colinesterase de pássaros que habitam áreas cultivadas \\ e áreas protegidas expostas a pesticidas na região semiárida quente do Paquistão
}

\author{
M. Umara (D), M. Hussain ${ }^{a *}$ (D) and S. K. Maloney ${ }^{\mathrm{b}}$ (D) \\ aUniversity of Gujrat, Faculty of Science, Department of Zoology, Punjab, Pakistan \\ ${ }^{\mathrm{b}}$ The University of Western Australia, School of Human Sciences, Perth, Australia
}

\begin{abstract}
Acetylcholinesterase (AChE) activity levels can be used as an indicator for AChE inhibition due to pesticide poisoning in bird species. We assessed the comparative brain cholinesterase (AChE) activity level of five bird species inhabiting pesticide exposed croplands and Protected Area i.e. Deva Vatala National Park (DVNP), Bhimber by using a spectrophotometric method. AChE activity levels ranged from 56.3 to $85.9 \mu \mathrm{mol} / \mathrm{min} / \mathrm{g}$ of brain tissue of birds representing DVNP. However, AChE activity levels ranged from 27.6 to $79.9 \mu \mathrm{mol} / \mathrm{min} / \mathrm{g}$ of brain tissue of birds representing croplands. AChE activity levels observed in Jungle babbler, Common babbler, and Red-vented bulbul showed significant differences $(\mathrm{P}<0.05)$ at two sites. However, White wagtail and Black drongo demonstrated non-significant differences $(P>0.05)$. Maximum inhibition was recorded in Jungle babbler $(53 \%)$ followed by Common babbler (35\%), Red-vented bulbul (18\%), White wagtail (15\%), and Black drongo (7\%). The brain cholinesterase inhibition levels under-protected ecosystems (DVNP, Bhimber) and agricultural landscape suggest insecticidal contamination and its impact on avifauna diversity. The study also emphasizes on the importance of pesticide-free zones to protect the biodiversity of birds.
\end{abstract}

Keywords: Agricultural landscapes, Gujrat, Black drongo, Insecticides, Avifauna.

\begin{abstract}
Resumo
Os níveis de atividade da acetilcolinesterase (AChE) podem ser usados como um indicador para a inibição da AChE devido ao envenenamento por pesticidas em espécies de aves. Avaliamos o nível de atividade comparativa da colinesterase cerebral (AChE) de cinco espécies de aves que habitam áreas cultivadas expostas a pesticidas e Área Protegida, ou seja, Deva Vatala National Park (DVNP), Bhimber, usando um método espectrofotométrico. Os níveis de atividade da AChE variaram de 56,3 a $85,9 \mu \mathrm{mol} / \mathrm{min} / \mathrm{g}$ de tecido cerebral de aves representando DVNP. No entanto, os níveis de atividade da AChE variaram de 27,6 a 79,9 $\mu \mathrm{mol} / \mathrm{min} / \mathrm{g}$ de tecido cerebral de aves representando áreas de cultivo. Os níveis de atividade de AChE observados no tagarela da selva, tagarela comum e bulbul vermelho exalado mostraram diferenças significativas $(\mathrm{P}<0,05)$ em dois locais. No entanto, alvéola branca e drongo preto demonstraram diferenças não significativas $(P>0,05)$. A inibição máxima foi registrada no tagarela da selva (53\%), seguido pelo tagarela comum (35\%), bulbul vermelho (18\%), alvéola branca (15\%) e drongo preto ( $7 \%$ ). Os níveis de inibição da colinesterase cerebral nos ecossistemas subprotegidos (DVNP, Bhimber) e na paisagem agrícola sugerem contaminação por inseticida e seu impacto na diversidade da avifauna. O estudo também enfatiza a importância das zonas livres de pesticidas para proteger a biodiversidade das aves.
\end{abstract}

Palavras-chave: Paisagens agrícolas, Gujrat, Drongo preto, Inseticidas, Avifauna.

\section{Introduction}

Insecticides are an integral part of crop protection strategies, however, their extensive use and toxicity results in biodiversity loss, reduce the population of beneficial organisms, and destabilize ecological resilience (Krebs et al., 1999; Oliver et al., 2015; Bashir et al., 2018; Huang et al., 2018; Wyckhuys et al., 2019; Khan et al., 2020).
Insects constitute the diet of about eighty percent of species of birds (Morse, 1975) and have great nutritional value (Klasing, 2000). The decrease in the insectivorous bird species has been reported from different agroecosystems (Hussain, 2005) associated with the decline in the population of insect fauna (Hallmann et al., 2014) and

*e-mail: dr.mubashar@uog.edu.pk

Received: February 17, 2021 - Accepted: April 20, 2021 
the use of insecticides (Goulson, 2014). The use of birds as indicators of pesticide-driven environmental change has been found very effective (Pimentel, 2005) as they forage on the crops that are exposed to pesticides (Rodenhouse et al., 1993). Organophosphates (OPs) and carbamate compounds produce toxic effects by inhibition of the activity of AChE resulting in the accumulation of acetylcholine (Dhalla and Sharma, 2013). The poison works by inhibiting the activity of the AChE, the enzyme that breaks down acetylcholine, resulting in higher levels of acetylcholine (Hallmann et al., 2014).

In mammals and birds, the higher levels of acetylcholinesterase manifest in increased saliva and tear production, diarrhea, vomiting, small pupils, sweating, muscle tremors, and confusion (Verheyen and Stoks, 2019). Death occurs ultimately via inhibition of cardiac output and bronchial constriction. For this reason, AChE activity has been used effectively as an index of pesticide exposure and can be used to monitor the impacts on off-target species (Wilson et al., 1992; Fossi et al., 1996), wherein a decrease in AChE activity can be considered as evidence of pesticide toxicity (O'Brien, 2014). The activity of brain cholinesterase in birds is used widely as an indicator of exposure to commonly used agricultural insecticides (Iko et al., 2003; Rendón-von Osten et al., 2005). For the assessment of any environmental contamination by pesticides, it is necessary to measure the brain cholinesterase activity periodically in a bird population (Fildes et al., 2009).

Lower levels of plasma or brain AChE activity than normal can be used as evidence of exposure to the pesticides resulting in mortality (Ludke et al., 1975). Such exposures may cause many sub-lethal effects such as decreased reproduction rate, as well as distortion of neurophysiological, physical, and behavioral activities (Grue et al., 1997).

Protected areas (PAs) play a significant role in biodiversity conservation but their effectiveness in conserving species and ecosystem which needs periodic assessments and comparisons between protected and unprotected sites (Joppa and Pfaff, 2009; Pressey et al., 2015; Cazalis et al., 2020). Inadequate data, lacking systematic monitoring systems, and counterfactual analysis between protected and unprotected areas have been reported (Andam et al., 2008; Gray et al., 2016; Cazalis et al., 2020).

We assessed the brain AChE activity in common species of the protected area and unprotected area and hypothesized that the use of pesticides in croplands adversely affecting bird species. We sampled bird species from agricultural croplands (Gujrat, Punjab, Pakistan) with a history of pesticide use and protected areas (DVNP, Bhimber) with no pesticide usage to evaluate the differences in brain AChE activity in bird species representing these habitats.

\section{Material and Methods}

\subsection{Study area}

The bird species selected for sampling brain cholinesterase activity (AChE) were collected from Gujrat and Deva Vatala National Park (DVNP), Bhimber (Figure 1). The AChE test samples were collected within a $5 \mathrm{~km}$ radius in the surroundings of the cropland area of Gujrat. The area under cultivation reflects two main cropping systems i.e. wheat is the major Rabi crop (winter), whereas rice, maize, and millet are the major Kharif crops (summer). The farmers, agriculture officers, wildlife officers, and marketing representatives of insecticide/herbicide companies were interviewed for data collection. Insecticides belonging to organophosphate, pyrethroid, and carbamate groups and herbicides are used routinely in these croplands to control the pest. The control samples for the AChE study were collected from the Deva Vatala National Park

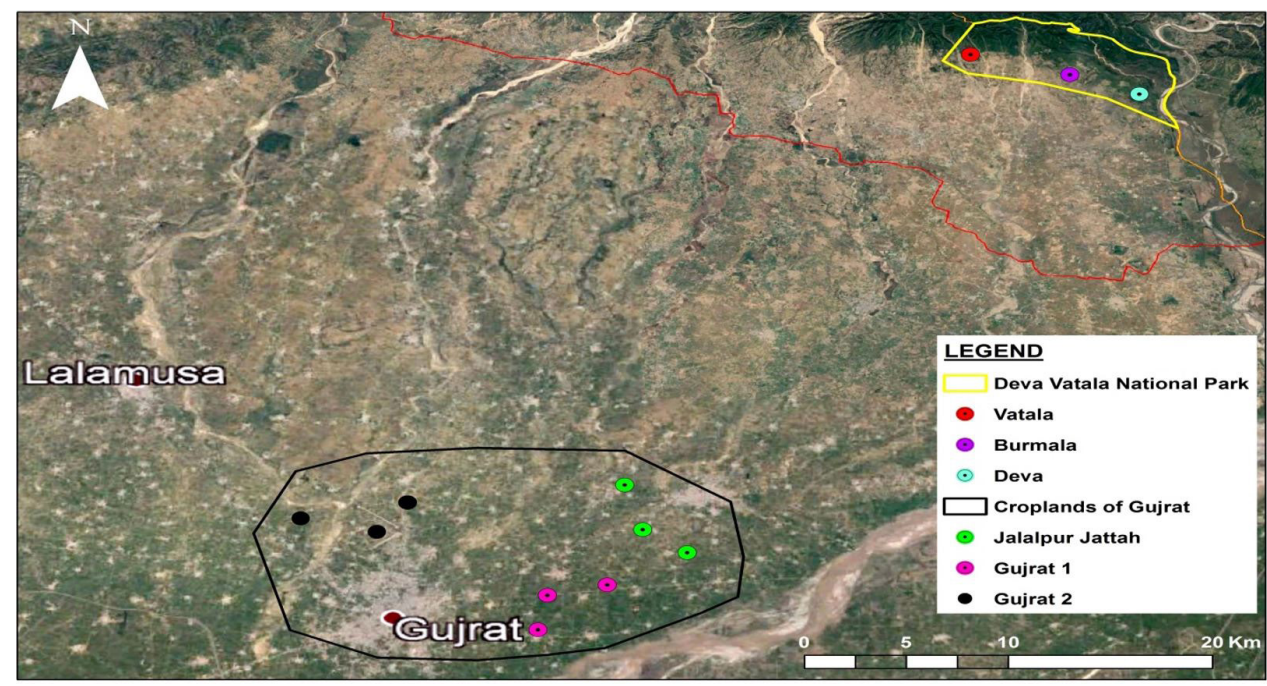

Figure 1. Data collection sites in Gujrat, Punjab, Pakistan and Deva Vatala National Park, Bhimber, AJK. 
(DVNP), Bhimber (Azad Jammu \& Kashmir), a pesticide-free protected area. Bird species that were common to these two areas were identified using the available literature (Grimmett et al., 2008).

\subsection{Analysis of brain AChE activity}

Five bird species (four insectivorous species and one omnivore red vented bulbul) seen in both Gujrat and DVNP were selected for the analysis of the brain AChE activity. During the cropping season (when pesticides are sprayed), three individuals of each species were shot dead and collected for the croplands whereas specimens (control group) were collected during the same period from the eastern edge of Deva Vatala Nation Park having a fair distance ( $>50 \mathrm{~km}$ from the croplands). The heads of the birds were immediately dissected from the body, sealed in a small plastic bag, tagged, and immediately stored in an ice chest. The samples were kept frozen while transporting to the laboratory where samples were stored at $-20^{\circ} \mathrm{C}$.

Briefly, 250 1 l of brain homogenate was mixed in a 96 plate well with $25 \mu$ l solution of 5,5'-dithio-2nitrobenzoic acid $(0.82 \mathrm{mg} / \mathrm{mL})$ followed by the addition of $25 \mu \mathrm{l}$ of the enzyme-substrate, acetylthiocholine $(6.7 \mathrm{mg} / \mathrm{mL})$ and the change in absorbance/min during a $5 \mathrm{~min}$ interval was measured at $405 \mathrm{~nm}$ using a Sunrise Microplate reader (Tecan Group Ltd., Männedorf, Switzerland). Enzyme activity was expressed in $\mu$ moles of acetylthiocholine hydrolyzed/ min/ gram of wet tissue.

The whole brain was homogenized in a phosphatebuffered solution ( $\mathrm{pH}=8.1$; concentration is $3 \mathrm{ml} / 100 \mathrm{mg}$ of tissue weight) for one minute. Samples were kept in glass test tubes for testing and placed in crushed ice. A spectrophotometric method for the determination of cholinesterase ( $\mathrm{ChE}$ ) activity in brain tissues of the birds was used to carry out this study. The assay of AChE activity was quantified following a modified method (Ellman et al., 1961). Enzymatic reactions were performed at $25^{\circ} \mathrm{C}$ in phosphate buffer (100 mM sodium phosphate, $\mathrm{pH} 7.5$ ) containing $0.5 \mathrm{mM}$ acetylthiocholine iodide and $0.5 \mathrm{mM}$ 5,5'-dithiobis-(2-nitrobenzoic acid) in a total volume of $100 \mu \mathrm{L}$. The specific activity of AChE was expressed as $\mu$ moles of acetylthiocholine iodide (ATChI) that hydrolyzed per $\mathrm{mg}$ protein/min and was calculated as:

$$
\begin{aligned}
& \text { Cholinesterase activity }=\left(\begin{array}{l}
\text { change in absorption } x \\
\mu \text { mol } x \text { reaction size } \mathrm{ml}
\end{array}\right) \\
& \left(\begin{array}{l}
\text { min } \times 13.6 \times \text { sample size } \mathrm{ml} \times \\
\text { tissue weight } \mathrm{gm} .
\end{array}\right)=\mu \mathrm{mol} / \mathrm{min} / \mathrm{g}
\end{aligned}
$$

\subsection{Statistical analysis}

The present study was designed as an oral subchronic toxicity study and results were analyzed using the General Linear Model (GLM) procedure of statistical analysis system (SAS) as a Completely Randomized Design. The results were analyzed using statistical variables and correlation coefficients. Means were compared using the Tukey-Kramer posthoc multiple comparison test $(P<0.05)$. The test results were analyzed by using Student's t-test between the control (DVNP) and the pesticide exposed (Gujrat) sites.

\section{Results}

We observed significant differences in brain acetylcholinesterase activities of the bird species. AChE activity levels (in ascending order) were recorded in Jungle babbler, White wagtail, Common babbler, Red-vented bulbul, and Black drongo captured from the croplands of Gujrat. Whereas a different order of AChE activity levels was observed in the bird species captured from DVNP i.e. White wagtail, Jungle babbler, Red-vented bulbul, Common babbler, and Black drongo (Table 1).

Bird species captured from the croplands of Gujrat showed a lower level of brain AChE activity than the samples collected from the Deva Vatala National Park (DVNP). At cropland of Gujrat, the lowest level of brain AChE activity was noted in jungle babbler $(27.6 \pm 1.41)$ whereas the highest level was in black drongo (79.9 \pm 10.80$)$. Furthermore, the highest value of the cholinesterase activity was observed in black drongo $(85.9 \pm 4.16)$ and lowest in white wagtail $(56.3 \pm 4.10)$ sampled from DVNP (Table 2).

The data indicated that jungle babbler, common babbler, and red vented bulbul have statistically significant $\mathrm{P}<0.05$ lower brain AChE enzyme activity of birds captured from Gujrat as compared to DVNP. However, white wagtail and black drongo do not show a significant difference (Table 1). Among all the bird species, the highest percentage of cholinesterase inhibition was observed in

Table 1. Cholinesterase activity ( $\mu \mathrm{mol} \mathrm{ChE} / \mathrm{min} / \mathrm{g}$ ) estimated in birds from Gujrat agro-ecosystem and Deva Vatala National Park (DVNP), Bhimber.

\begin{tabular}{cccc}
\hline Bird species & DVNP & Gujrat & P-value \\
\hline Jungle babbler & $58.7 \pm 3.27^{\mathrm{a}}$ & $27.6 \pm 1.41^{\mathrm{b}}$ & 0.0001 \\
White wagtail & $56.3 \pm 4.10^{\mathrm{a}}$ & $47.9 \pm 6.56$ & 0.1321 \\
Common babbler & $84.5 \pm 3.56^{\mathrm{a}}$ & $54.8 \pm 7.21^{\mathrm{b}}$ & 0.0031 \\
Red Vented bulbul & $68.2 \pm 3.73^{\mathrm{a}}$ & $55.9 \pm 1.59^{\mathrm{b}}$ & 0.0062 \\
Black drongo & $85.9 \pm 4.16$ & $79.9 \pm 10.80$ & 0.4224 \\
\hline
\end{tabular}

Values are mean \pm SE of bird species. Mean values within a row with different letters are significantly different from each other at $p<0.05$. 
Table 2. Inhibition (\%) of brain AChE activities level in birds at croplands of Gujrat and Deva Vatala National Park (DVNP), Bhimber.

\begin{tabular}{|c|c|c|c|}
\hline \multirow[t]{2}{*}{ Bird Species } & \multicolumn{2}{|c|}{ Cholinesterase Activity $(\mu \mathrm{mol} / \mathrm{min} / \mathrm{g}$ ) } & \multirow[t]{2}{*}{ Inhibition (\%) } \\
\hline & DVNP & Gujrat & \\
\hline \multirow[t]{3}{*}{ White wagtail } & 60.50 & 42.30 & \\
\hline & 52.30 & 46.20 & \\
\hline & 56.10 & 55.10 & 15 \\
\hline Mean & $56.3 \pm 4.10$ & $47.8 \pm 6.56$ & \\
\hline CV (\%) & 7.3 & 13.7 & \\
\hline \multirow[t]{3}{*}{ Red-vented bulbul } & 71.40 & 56.30 & \\
\hline & 69.10 & 57.20 & \\
\hline & 64.10 & 54.10 & 18 \\
\hline Mean & $68.2 \pm 3.73$ & $55.87 \pm 1.59$ & \\
\hline CV (\%) & 5.47 & 2.85 & \\
\hline \multirow[t]{3}{*}{ Black drongo } & 90.40 & 87.00 & \\
\hline & 85.10 & 85.30 & \\
\hline & 82.20 & 67.50 & 7 \\
\hline Mean & $85.9 \pm 4.16$ & $79.93 \pm 10.80$ & \\
\hline CV (\%) & 4.84 & 13.51 & \\
\hline \multirow[t]{3}{*}{ Jungle babbler } & 61.70 & 26.30 & \\
\hline & 59.10 & 27.40 & \\
\hline & 55.20 & 29.10 & 53 \\
\hline Mean & $58.67 \pm 3.27$ & $27.6 \pm 1.41$ & \\
\hline CV (\%) & 5.58 & 5.11 & \\
\hline \multirow[t]{3}{*}{ Common babbler } & 88.20 & 59.50 & \\
\hline & 84.12 & 58.40 & \\
\hline & 81.10 & 46.50 & 35 \\
\hline Mean & $84.47 \pm 3.56$ & $54.8 \pm 7.21$ & \\
\hline CV (\%) & 4.22 & 13.16 & \\
\hline
\end{tabular}

CV: Coeficient of variation.

Jungle babbler ( $53 \%$ ) followed by Common babbler (35\%), Red-vented bulbul (18\%), White wagtail (15\%), and black drongo (7\%) (Table 2).

The analysis of variance indicated significant differences in mean values of AChE activity of brain of bird species between sites $\left(\mathrm{F}_{(1,20)}=79.79558, \mathrm{P}=0.000\right)$, species $\left(\mathrm{F}_{(4,20)}=49.54177, \mathrm{P}=0.000\right)$ and a significant interaction
$\left(F_{(4,20)}=7.48464, P=0.000\right)$. The brain AChE activity showed significant differences between species except for White wagtail, Jungle babbler, Red-vented bulbul, and Common babbler. However, the values were significant between species and sites for only Common babbler and Jungle babbler (Table 3). 


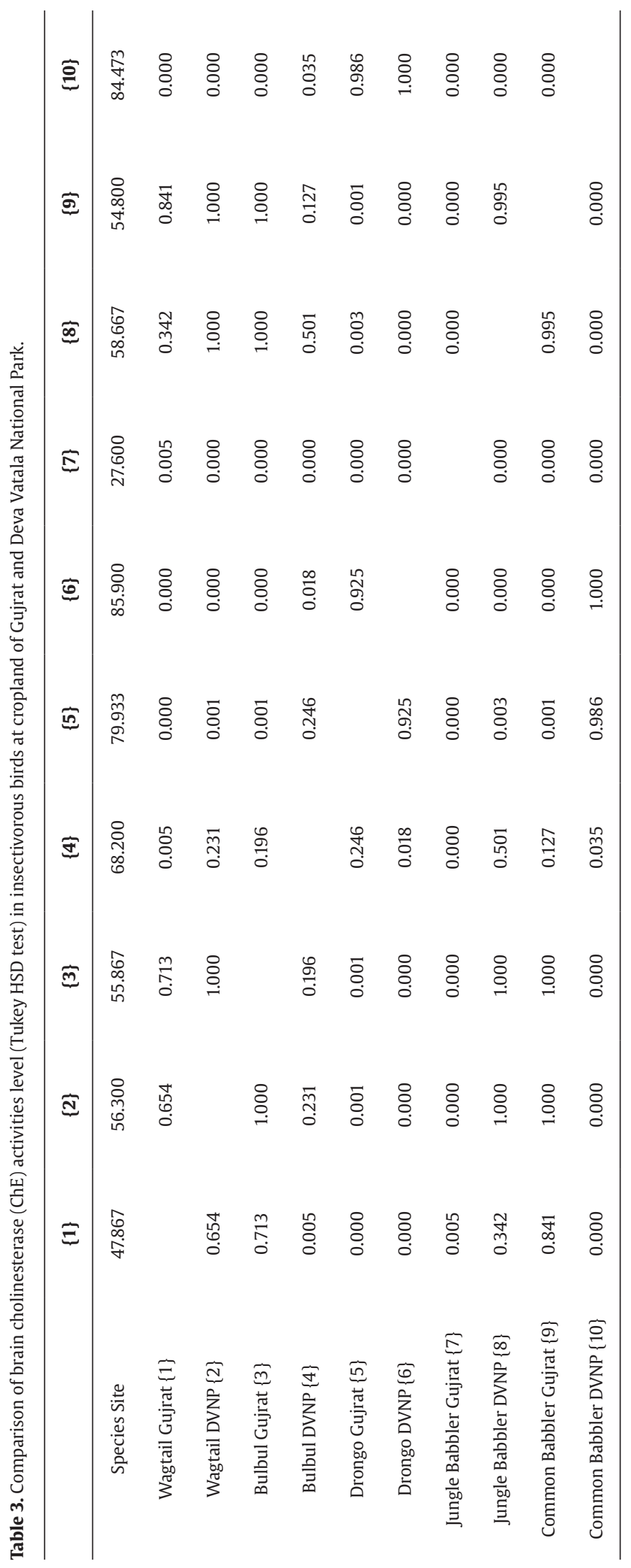




\section{Discussion}

Wild birds have been reported frequently for their exposures to anticholinergic pesticide poisoning (Blakley and Yole, 2002; Kim et al., 2008; Shimshoni et al., 2012; Kim et al., 2016; Bang et al., 2019). Our study area is characterized by increased human activity, habitat disturbance, and agricultural practices (Umar et al., 2021).

In our study, we assessed brain AChE activity of four insectivore species (Common babblers, Jungle babblers, Black drongo, and White wagtail) and one omnivore species (Red vented bulbul). These species move towards areas having a better shelter to avoid the severity of temperature rise and exploit vegetation cover inhabiting more insect fauna to meet their dietary requirements (Brommer et al., 2012; Kaur and Kler, 2018).

The richness of insectivores increases with the increase in natural vegetation and declines with increased urbanization (Lim and Sodhi, 2004; Kaur and Kler, 2018). Black drongo, one of the key insectivore species that inhabits the agricultural areas and avoids higher elevations (Wiersma et al., 2016). In an earlier study, Black drongo was observed as a competent predator of insects (Kaur and Kler, 2018; Bilal et al., 2020). White wagtail and black drongo did not show a significant reduction in the activity level of brain AChE. It may be attributed to their traveling across large areas i.e. visiting different ecosystems (Hussain et al., 2006). Furthermore, black drongo was not solely dependent on agricultural landscapes, thus, may have little exposure to pesticide-contaminated diets. Black drongo prefers the edges of the cropland and heterogeneous habitats. It has an aerial feeding habit of preying on flying insects like dragonflies, moths, and honey bees (Kaur and Kler, 2018).

Whereas white wagtail was a resident bird found in open fields near the urban area in Pakistan (Roberts, 1991). Common Babbler and jungle babbler were also resident species of the agroecosystems. The higher diversity of these insectivore species, as recorded in our study, owes to agricultural landscapes that provide habitat for larvae of flying insects. Common Babbler and jungle babbler were also recorded from the agroecosystem of Multan, Pakistan (Hussain, 2005). The Red-vented Bulbul is a resident, non-territorial species commonly found in croplands and forests, feed on a variety of cultivated plants (Islam and Williams, 2000). Red-vented bulbul is associated with locally nomadic in response to nectar abundance (Grimmett et al., 2008). Omnivorous species have adapted to the urban environment and its particular food resources such as garbage (Clergeau et al., 2006). Red-vented bulbul was more tolerant towards human disturbances because omnivorous species do exploit anthropogenic food resources effectively (Jokimäki and Suhonen, 1998). We explored that the activity level of brain AChE of all bird species representing cropland was lower as compared to birds of DVNP. It is more likely that this higher level of AChE recorded was the result of pesticide-free habitat whereas, lower levels of AChE were found in birds representing cropland suggests pesticide contamination of the habitat. Similarly, lower activity levels of AChE were reported in birds from the cotton-based agroecosystem of Multan, Pakistan (Hussain et al., 2006). In our study, Jungle babbler, Common babbler, White wagtail, Black drongo, and Red-vented bulbul were the resident species of croplands that were expected to be having insecticidal exposures during feeding activity. Similar findings were reported in earlier studies conducted in the agro-ecosystem of Punjab (Hussain, 2005).

Our study area having a history of regular pesticide application may pose threat to bird fauna feeding on insects, grains, etc. A similar conclusion was reported regarding pesticide risk to birds in the agricultural landscapes of Pakistan (Hussain et al., 2006). The farming community of the cotton belt of Punjab believes that increased pesticide use has resulted in the decline of avian diversity (Khan et al., 2002). Our results regarding brain AChE inhibition were sufficient to provide evidence that the insectivorous birds inhabiting the croplands of Punjab may be at the risk of being adversely affected by pesticide pollution. Similar results were reported for jungle babbler and Indian wren warbler from cotton growing areas (Hussain, 2005). Higher levels of pesticide exposures affect the reproductive system, viability of eggs, hatching, nestling growth, and adult survival (Rodenhouse and Holmes, 1992). All the bird species except the red vented bulbul were insectivores. Thus, these bird species are supposedly having higher levels of pesticide poisoning threats in the agricultural landscapes due to regular pesticide application (Jabbar et al., 1993; Hasnain, 1999).

White wagtail prefers to inhabit the near household areas and aerial feeding. It may occasionally feed on the croplands only during traveling. This may be the reason for the activity level of brain ChE of these birds showed non-significant differences between the two landscape types under study. Jungle babbler and common babbler were the bird species that inhabited particularly cropland areas, thus, they showed a significant difference in the activity level of brain AChE. Jungle babbler occurs in habitats with trees and occupies ranging from dry deciduous woodland to semi-arid cropland (Gaston, 1978). These birds have omnivorous feeding habits with insects forming the predominant portion of their diet. Its feeding method was close to the ground feeding on surface-dwelling insects (Anthal and Sahi, 2013). Common babbler, Turdoides caudatus is a resident bird species in tropical and lower subtropical latitudes. It inhabits agricultural landscapes, semi-arid regions, and also into the forests of the southeast of the Western Palearctic (Ali and Ripley, 1971). The higher value of inhibition in the jungle babbler (53\%) and common babbler (35\%) is attributed to their habitat and activity preferences that were limited only to the croplands. However, in red vented bulbul, the level of inhibition was only $18 \%$ that showed a significant difference in the activity level of Brain AChE. The lower inhibition percentage could be due to its feeding habit that was not limited to insects but omnivore feeding. The similar adverse effects of the pesticide on AChE inhibition in birds suggest a high level of risk to avian diversity (Hussain et al., 2006). An earlier report about farmers' perception of the reduction in bird diversity in the agricultural landscapes of Pakistan also supports the views of the negative impacts of pesticides on bird diversity (Khan et al., 2002). This study suggested further investigations for the assessment and determination of pesticide residues, their effect on reproductive potential, and particularly viability of the insectivorous birds and avian fauna, in general, at agro-ecosystems. 


\section{Conclusion}

Significant differences were noted in AChE activity levels of bird species between Gujrat croplands and protected area (DVNP). These variable responses of species may be attributed to their diverse feeding, perching, and other interactive behaviors. The results confirmed cholinesterase inhibition activity of brains in the birds captured from croplands of Gujrat. Our results suggest that the use of insecticides in croplands may lead to lower feed availability due to lower insect abundance ultimately resulting in a lower abundance of insectivore birds. Our results of AChE activity levels indicated that bird species inhabiting or visiting croplands for feed are adversely affected by insecticide poisoning. This study highlights the importance of protected areas associated with croplands in the conservation of bird species.

\section{References}

ALI, S. and RIPLEY, S.D., 1971. Handbook of the Birds of India and Pakistan: Cuckoo-shrikes to babaxes. Reino Unido: Oxford University Press, vol. 6.

ANDAM, K.S., FERRARO, P.J., PFAFF, A., SANCHEZ-AZOFEIFA, G.A. and ROBALINO, J.A., 2008. Measuring the effectiveness of protected area networks in reducing deforestation. Proceedings of the National Academy of Sciences of the United States of America, vol. 105, no. 42, pp. 16089-16094. http://dx.doi.org/10.1073/ pnas.0800437105. PMid:18854414.

ANTHAL, A. and SAHI, D., 2013. Food and feeding ecology of jungle babbler, Turdoides striatus sindianus (Ticehurst) in District Jammu (J\&K), India. International Research Journal of Environment Sciences, vol. 2, pp. 54-57.

BANG, J.-H., KU, H.-O., KANG, H.-G., KIM, H., KIM, S., PARK, S.-W., KIM, Y.-S., JANG, I., BAE, Y.-C., WOO, G.-H. and YI, H., 2019. Acetylcholinesterase activity in the brain of wild birds in Korea-2014 to 2016. Journal of Veterinary Science, vol. 20, no. 2, pp. e9. http://dx.doi.org/10.4142/jvs.2019.20.e9. PMid:30944532.

BASHIR, M.H., ZAHID, M., KHAN, M.A., SHAHID, M., KHAN, A.K. and AMRAO, L., 2018. Pesticides toxicity for Neoseiulus barkeri (Acari: Phytoseiidae) and non-target organisms. Pakistan Journal of Agricultural Sciences, vol. vol. 55, no. 1, pp. 63-71. http:// dx.doi.org/10.21162/PAKJAS/18.5277.

BILAL, M., KHALID, Z., MOSVI, A.H. and NASEER, A., 2020. Feeding Ecology, Behaviour and Habitat Utilization of Black Drongo (Dicrurus Macrocercus) in Pothwar Plateau, Pakistan. Journal of Bioresource Management, vol. 7, no. 2, pp. 6. http://dx.doi. org/10.35691/JBM.0202.0131.

BLAKLEY, B.R. and YOLE, M.J., 2002. Species differences in normal brain cholinesterase activities of animals and birds. Veterinary and Human Toxicology, vol. 44, no. 3, pp. 129-132. PMid: 12046961.

BROMMER, J.E., LEHIKOINEN, A. and VALKAMA, J., 2012. The breeding ranges of Central European and Arctic bird species move poleward. PLoS One, vol. 7, no. 9, pp. e43648. http:// dx.doi.org/10.1371/journal.pone.0043648. PMid:23028465.

CAZALIS, V., PRINCÉ, K., MIHOUB, J.-B., KELLY, J., BUTCHART, S.H. and RODRIGUES, A.S., 2020. Effectiveness of protected areas in conserving tropical forest birds. Nature Communications, vol. 11, no. 1, pp. 4461. http://dx.doi.org/10.1038/s41467-02018230-0. PMid:32929068.

CLERGEAU, P., CROCI, S., JOKIMÄKI, J., KAISANLAHTI-JOKIMÄKI, M.-L. and DINETTI, M., 2006. Avifauna homogenisation by urbanisation: analysis at different European latitudes.
Biological Conservation, vol. 127, no. 3, pp. 336-344. http:// dx.doi.org/10.1016/j.biocon.2005.06.035.

DHALLA, A.S. and SHARMA, S., 2013. Assessment of serum cholinesterase in rural Punjabi sprayers exposed to a mixture of pesticides. Toxicology International, vol. 20, no. 2, pp. 154-159. http://dx.doi.org/10.4103/0971-6580.117258. PMid:24082509.

ELLMAN, G.L., COURTNEY, K.D., ANDRES JUNIOR, V. and FEATHERSTONE, R.M., 1961. A new and rapid colorimetric determination of acetylcholinesterase activity. Biochemical Pharmacology, vol. 7, no. 2, pp. 88-95. http://dx.doi. org/10.1016/0006-2952(61)90145-9. PMid:13726518.

FILDES, K., SZABO, J.K., HOOPER, M.J., BUTTEMER, W.A. and ASTHEIMER, L.B., 2009. Plasma cholinesterase characteristics in native Australian birds: significance for monitoring avian species for pesticide exposure. Emu-Austral Ornithology, vol. 109, no. 1, pp. 41-47. http://dx.doi.org/10.1071/MU08027.

FOSSI, M.C., LARI, L. and CASINI, S., 1996. Interspecies variation of "B" esterases in birds: the influence of size and feeding habits. Archives of Environmental Contamination and Toxicology, vol. 31, no. 4, pp. 525-532. http://dx.doi.org/10.1007/BF00212436. PMid:8975825.

GASTON, A., 1978. Ecology of the common babbler Turdoides caudatus. The Ibis, vol. 120, no. 4, pp. 415-432. http://dx.doi. org/10.1111/j.1474-919X.1978.tb06809.x.

GOULSON, D., 2014. Pesticides linked to bird declines. Nature, vol. 511, no. 7509, pp. 295-296. http://dx.doi.org/10.1038/ nature13642. PMid:25030159.

GRAY, C.L., HILL, S.L., NEWBOLD, T., HUDSON, L.N., BÖRGER, L., CONTU, S., HOSKINS, A.J., FERRIER, S., PURVIS, A. and SCHARLEMANN, J.P., 2016. Local biodiversity is higher inside than outside terrestrial protected areas worldwide. Nature Communications, vol. 7, no. 1, pp. 1-7. http://dx.doi.org/10.1038/ ncomms12306. PMid:27465407.

GRIMMETT, R., ROBERTS, T.J., INSKIPP, T. and BYERS, C., 2008. Birds of Pakistan. London: A\&C Black.

GRUE, C.E., GIBERT, P.L. and SEELEY, M.E., 1997. Neurophysiological and behavioral changes in non-target wildlife exposed to organophosphate and carbamate pesticides: thermoregulation, food consumption, and reproduction. American Zoologist, vol. 37, no. 4, pp. 369-388. http://dx.doi.org/10.1093/icb/37.4.369.

HALLMANN, C.A., FOPPEN, R.P., VAN TURNHOUT, C.A., DE KROON, H. and JONGEJANS, E., 2014. Declines in insectivorous birds are associated with high neonicotinoid concentrations. Nature, vol. 511, no. 7509, pp. 341-343. http://dx.doi.org/10.1038/ nature13531. PMid:25030173.

HASNAIN, T., 1999. Pesticide use and its impact on crop ecologies: issues and options. Islamabad: Sustainable Development Policy Institute. (SDPI Working Paper Series).

HUANG, J., ZHOU, K., ZHANG, W., DENG, X., VAN DER WERF, W., LU, Y., WU, K. and ROSEGRANT, M.W., 2018. Uncovering the economic value of natural enemies and true costs of chemical insecticides to cotton farmers in China. Environmental Research Letters, vol. 13, no. 6, pp. 064027. http://dx.doi.org/10.1088/17489326/aabfb0.

HUSSAIN, I., 2005. Insectivorous Birds and Their Significance in a Cotton Wheat Based Agro-ecosystem of Punjab, Pakistan. Pakistan Journal of Zoology, vol. 37, pp. 133-143.

HUSSAIN, I., NAUREEN, H. and AHMED, I., 2006. A preliminary study on risk analysis of pesticides to insectivorous birds inhabiting cotton based agro-ecosystem of Punjab, Pakistan. Pakistan Journal of Zoology, vol. 38, pp. 255-260.

IKO, W.M., ARCHULETA, A.S. and KNOPF, F.L., 2003. Plasma cholinesterase levels of Mountain Plovers (Charadrius montanus) wintering in central California, USA. Environmental Toxicology and Chemistry: An International Journal, vol. 22, no. 1, pp. 119125. http://dx.doi.org/10.1002/etc.5620220115. PMid:12503754. 
ISLAM, K., and WILLIAMS, R.N., 2000. Red-vented Bulbul (Pycnonotus cafer) and Red-whiskered Bulbul (Pycnonotus jocosus). In: A. POOLE and F. GILL, eds. The Birds of North America. Ithaca: Cornell Laboratory of Ornithology.

JABBAR, A., MASUD, S.Z., PARVEEN, Z. and ALI, M., 1993. Pesticide residues in cropland soils and shallow groundwater in Punjab Pakistan. Bulletin of Environmental Contamination and Toxicology, vol. 51, no. 2, pp. 268-273. http://dx.doi.org/10.1007/BF00198891. PMid:8353391.

JOKIMÄKI, J. and SUHONEN, J., 1998. Distribution and habitat selection of wintering birds in urban environments. Landscape and Urban Planning, vol. 39, no. 4, pp. 253-263. http://dx.doi. org/10.1016/S0169-2046(97)00089-3.

JOPPA, L.N. and PFAFF, A., 2009. High and far: biases in the location of protected areas. PLoS One, vol. 4, no. 12, pp. e8273. http:// dx.doi.org/10.1371/journal.pone.0008273. PMid:20011603.

KAUR, G. and KLER, T.K., 2018. Feeding behaviour and perching preferences of black drongo (Dicrurus macrocercus) in Ludhiana district (Punjab). Journal of Entomology and Zoology Studies, vol. 6, pp. 232-239.

KHAN, M.A., IQBAL, M., AHMAD, I., SOOMRO, M.H. and CHAUDHARY, M.A., 2002. Economic evaluation of pesticide use externalities in the cotton zones of Punjab, Pakistan. Pakistan Development Review, vol. 41, no. 4, pt II, pp. 683-698. http://dx.doi. org/10.30541/v41i4IIpp.683-698.

KHAN, M.I., SHOUKAT, M.A., CHEEMA, S.A., ARIF, H.N., NIAZI, N.K., AZAM, M., BASHIR, S., ASHRAF, I. and QADRI, R., 2020. Use, Contamination and Exposure of Pesticides in Pakistan: A Review. Pakistan Journal of Agricultural Sciences, vol. 57, pp. 131-149.

KIM, M., YUN, S.J., KIM, D.-G., BONG, Y.-H., KIM, H., JANG, J.-H. and CHUNG, G.-S., 2008. Determination of pesticides in dead wild birds in Korea. Korean Journal of Veterinary Research, vol. 48, pp. 131-137.

KIM, S., PARK, M.-Y., KIM, H.-J., SHIN, J.Y., KO, K.Y., KIM, D.-G., KIM, M., KANG, H.-G., SO, B. and PARK, S.-W., 2016. Analysis of insecticides in dead wild birds in Korea from 2010 to 2013. Bulletin of Environmental Contamination and Toxicology, vol. 96 , no. 1, pp. 25-30. http://dx.doi.org/10.1007/s00128-015-1688-0. PMid:26573839.

KLASING, K., 2000. Comparative Avian Nutrition CABI Publishing. Wallingford: $C A B$ International.

KREBS, J.R., WILSON, J.D., BRADBURY, R.B. and SIRIWARDENA, G.M., 1999. The second silent spring? Nature, vol. 400, no. 6745, pp. 611-612. http://dx.doi.org/10.1038/23127.

LIM, H.C. and SODHI, N.S., 2004. Responses of avian guilds to urbanisation in a tropical city. Landscape and Urban Planning, vol. 66, no. 4, pp. 199-215. http://dx.doi.org/10.1016/S01692046(03)00111-7.

LUDKE, J.L., HILL, E.F. and DIETER, M.P., 1975. Cholinesterase (ChE) response and related mortality among birds fed $\mathrm{ChE}$ inhibitors. Archives of Environmental Contamination and Toxicology, vol. 3, no. 1, pp. 1-21. http://dx.doi.org/10.1007/BF02221128. PMid:1130829.

MORSE, D.H., 1975. Ecological aspects of adaptive radiation in birds. Biological Reviews of the Cambridge Philosophical Society, vol. 50, no. 2, pp. 167-214. http://dx.doi.org/10.1111/j.1469185X.1975.tb01056.x.

O'BRIEN, R.D., 2014. Insecticides: action and metabolism. Cambridge: Academic Press.

OLIVER, T.H., ISAAC, N.J., AUGUST, T.A., WOODCOCK, B.A., ROY, D.B. and BULLOCK, J.M., 2015. Declining resilience of ecosystem functions under biodiversity loss. Nature Communications, vol.
6, no. 1, pp. 10122. http://dx.doi.org/10.1038/ncomms10122. PMid:26646209.

PIMENTEL, D., 2005. Aquatic nuisance species in the New York State Canal and Hudson River systems and the Great Lakes Basin: an economic and environmental assessment. Environmental Management, vol. 35, no. 5, pp. 692-702. http://dx.doi. org/10.1007/s00267-004-0214-7. PMid:15920670.

PRESSEY, R.L., VISCONTI, P. and FERRARO, P.J., 2015. Making parks make a difference: poor alignment of policy, planning and management with protected-area impact, and ways forward. Philosophical Transactions of the Royal Society of London. Series B, Biological Sciences, vol. 370, no. 1681, pp. 20140280. http:// dx.doi.org/10.1098/rstb.2014.0280. PMid:26460132.

RENDÓN-VON OSTEN, J., SOARES, A.M.V.M. and GUILHERMINO, L., 2005. Black-bellied whistling duck (Dendrocygna autumnalis) brain cholinesterase characterization and diagnosis of anticholinesterase pesticide exposure in wild populations from Mexico. Environmental Toxicology and Chemistry, vol. 24, no. 2, pp. 313-317. http://dx.doi.org/10.1897/03-646.1. PMid:15719990.

ROBERTS, T.J., 1991. The Birds of Pakistan: Passeriformes: Pittas to Buntings. USA: Oxford University Press, Vol. 2.

RODENHOUSE, N.L. and HOLMES, R.T., 1992. Results of experimental and natural food reductions for breeding black-throated blue warblers. Ecology, vol. 73, no. 1, pp. 357-372. http://dx.doi. org/10.2307/1938747.

RODENHOUSE, N.L., BEST, L.B., O'CONNOR, R.J. and BOLLINGER, E.K. 1993. Effects of temperate agriculture on neotropical migrant landbirds. In: D.M. FINCH, P.W. STANGEL, ROCKY MOUNTAIN FOREST AND RANGE EXPERIMENT STATION (FORT COLLINS, COLO., and U.S. FISH AND WILDLIFE SERVICE, eds. Status and management of neotropical migratory birds: September 21-25, 1992, Estes Park, Colorado. Fort Collins, Colo.: Rocky Mountain Forest and Range Experiment Station, US Dept. of Agriculture, pp. 280-295, Series: General technical report RM; no. 229.

SHIMSHONI, J., EVGENY, E., LUBLIN, A., CUNEAH, O., KING, R., HOROWITZ, I. and SHLOSBERG, A., 2012. Determination of brain cholinesterase activity in normal and pesticide exposed wild birds in Israel. Israel Journal of Veterinary Medicine, vol. 67, pp. 214-219.

UMAR, M., HUSSAIN, M., MALIK, M.F., AWAN, M.N. and LEE, D.C., 2021. Avian community Composition and Spatio-Temporal Patterns at Deva Vatala National Park. Pakistan Journal of Zoology, vol. 53, no. 3, pp. 921-929. https://dx.doi.org/10.17582/journal. pjz/20190711190734.

VERHEYEN, J. and STOKS, R., 2019. Current and future daily temperature fluctuations make a pesticide more toxic: contrasting effects on life history and physiology. Environmental Pollution, vol. 248, pp. 209-218. http://dx.doi.org/10.1016/j. envpol.2019.02.022. PMid:30798022.

WIERSMA, P., KIRWAN, G. and BOESMAN, P., 2016. Two-banded Plover (Charadrius falklandicus). In: J. DEL HOYO, A. ELLIOTT, J. SARGATAL, D. A. CHRISTIE and E. DE JUANA, eds. Handbook of the birds of the world alive. Barcelona: Lynx Edicions.

WILSON, B., HOOPER, P., HANSEN, M. and NIEBERG, P. 1992. Reactivation of organophosphorus inhibited AChE with oximes. In: J.E. CHAMBERS and P.E. LEVI, eds. Organophosphates chemistry, fate and effects. New York: Academic Press, pp. 107-131. http:// dx.doi.org/10.1016/B978-0-08-091726-9.50009-4.

WYCKHUYS, KA G., HEONG, K.L., SANCHEZ-BAYO, F., BIANCHI, F.J.J.A., LUNDGREN, J.G. and BENTLEY, J.W., 2019. Ecological illiteracy can deepen farmers' pesticide dependency. Environmental Research Letters, vol. 14, no. 9, pp. 093004. http://dx.doi. org/10.1088/1748-9326/ab34c9. 